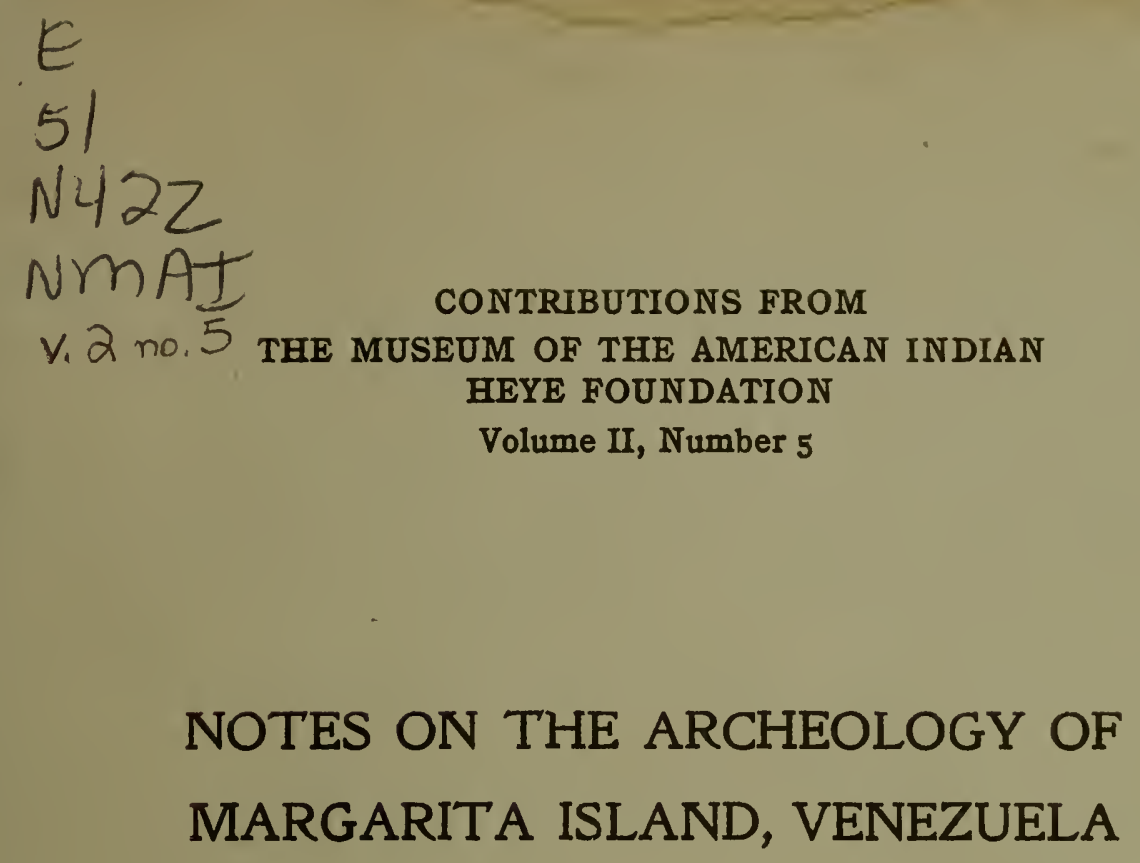

BY

THEODOOR DE BOOY

NEW YORK

THE MUSEUM OF THE AMERICAN INDIAN

HEYE FOUNDATION

Io EAST THIRTY-THIRD STREET

I916

JUL 202000 



\section{NOTES ON THE ARCHEOLOGY OF MARGARITA ISLAND, VENEZUELA}

BY

\section{THEODOOR DE BOOY}

\section{INTRODUCTION}

T was the privilege of the writer to spend the months of February; March, and April, I915, on the island of Margarita, off the northern coast of Venezuela, in the interest of the Museum of the American Indian (Heye Foundation), with the object of studying the cultural remains of its former aboriginal inhabitants.

After leaving New York, the writer's first stay was in Caracas, the capital of Venezuela, where he presented letters of introduction from Dr Santos A. Dominici, Minister of Venezuela to the United States, to various Government officials, who in turn provided him with credentials directing the civil and military authorities to further the interests of the expedition. In addition to these courtesies, the writer's equipment was permitted to enter free of duty. It is with great pleasure, therefore, that he embraces this opportunity to express his sincere gratitude to the Venezuelan Government, and particularly to General Ignacio Andrade, Minister of the Exterior; Dr Pedro Manuel Arcaya, Minister of the Interior; Mr C. F. Witzke, Director of the National Museums of Venezuela, and Dr Guevara Rojas, Minister of Public Instruction. In addition sincere thanks are extended to Dr Santos A. Dominici, Venezuelan Minister at Washington, and to Mr F. J. Yánes of the Pan American Union, for their courteous and influential letters of introduction.

The writer also received great aid and was shown many courtesies by the Government officials of the island of Margarita. General Juan Alberto Ramirez, State President of Nueva Esparta, the state in which Margarita lies, especially facilitated the investigations in every possible way. Grateful thanks are due also to 
Mr Charles Freeman, of Porlamar, manager of the local magnesite mines, to Dr Benigno Campos, physician of Porlamar, and to General José Maria Bermudez.

\section{Situation OF THE ISLAND}

Margarita is situated between latitude $10^{\circ} 52^{\prime}$ and II $^{\circ}$ I I' $\mathrm{N}$., and longitude $63^{\circ} 47^{\prime}$ and $64^{\circ} 24^{\prime} \mathrm{IV}$. The maximum width of the island is about 37 miles, and the greatest distance from north to south about I9 miles. The nearest points of approach between Margarita and Araya peninsula of the mainland, namely, Point Mangles and Point Morro de la Peña, are 12 $1 / 2$ miles apart. From the latter point on the mailand to the western point of Coche, the island lying in the passage between the mainland and Margarita, is a distance of eight miles, and from the western point of Coche to Point Mangles on Margarita is a distance of only six miles. It is therefore obvious that communication between Margarita and the mainland by means of canoes in pre-Columbian times was an easy matter, especially as the seas here are invariably tranquil. The accompanying map (fig. I) is copied from chart 2035 of the United States Hydrographic Office, with the addition of the names of such pueblos and other localities as are referred to in this paper.

There is now little communication between Margarita island and the coastal towns of Venezuela, consequently the writer was obliged to travel from La Guayra (the principal port of the Republic and the port of entry for Caracas) to Cumana on a steamer of the Royal Dutch IVest India Line in order to connect with the Venezuelan coastal steamer for Margarita at the latter town. The port of Cumana is called Pucrto Sucre. Between this port and Cumana lies a small fishing village of the Guaiqueria Indians, who at the time of the Spanish conquest inhabited the peninsula of Araya and the island of Margarita.

\section{The Guaiqueria Inhabitants}

Speaking of the Guaiqueria, Humboldt says:

"The name of this tribe of Indians was quite unknown before the conquest. The natives who bear this name formerly belonged to the 
nation of the Guaraounoes, of which we find no remains but in the swampy lands of the Oroonoko. Old men have assured me, that the language of their ancestors was a dialect of the Guaraouno; but that for a century past no native of that tribe at Cumana, or in the island of Margaretta, has spoken any other language than the Castilian.

"The denomination of Guayquerias, like those of Peru and Peruvian,

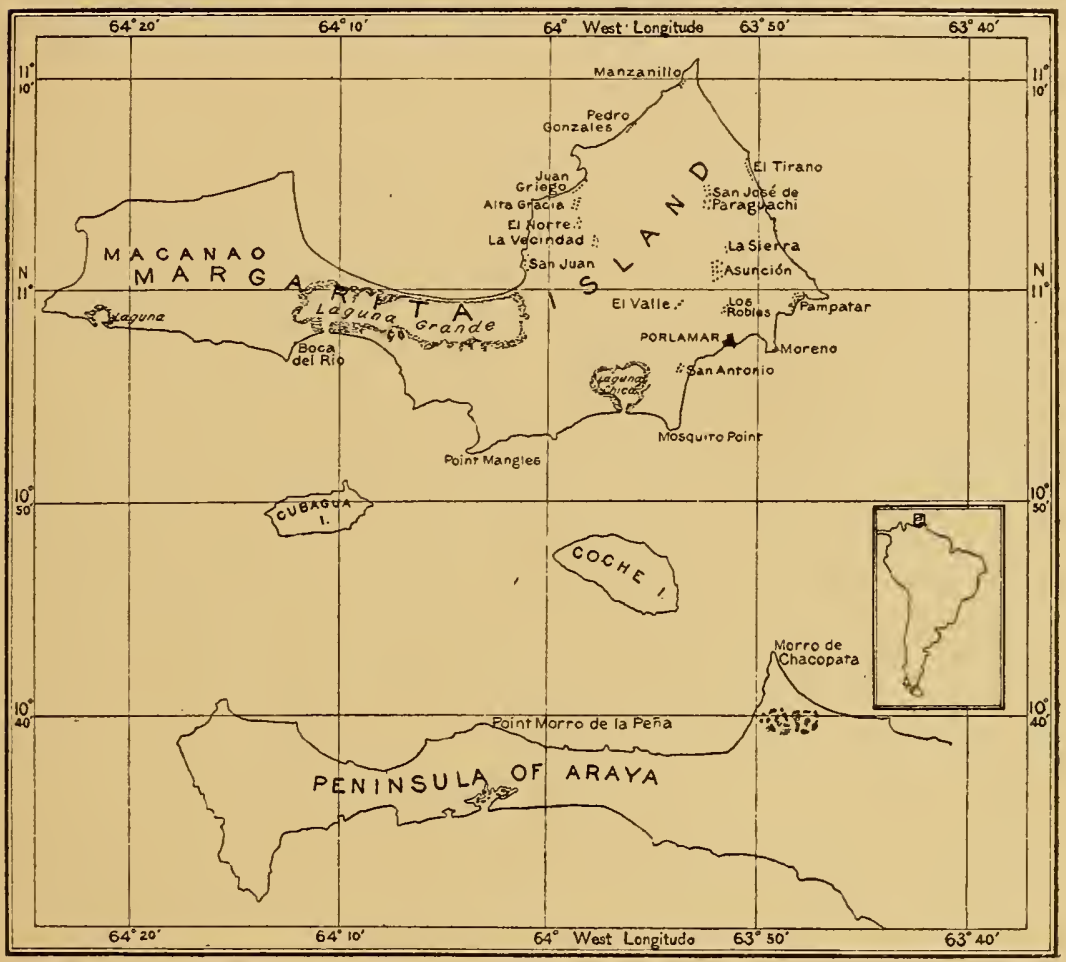

FIG. I.-Map of Margarita Island and the adjacent mainland.

owes it's origin to a mere mistake. The companions of Christopher Columbus, coasting along the island of Margaretta where still on the northern coasts resides the noblest portion of the Guayqueria nation, met a few natives, who were harpooning fish by throwing a pole tied to a cord, and terminated by an extremely sharp point. They asked them in the Hayti language their name; and the Indians, thinking that the question of the strangers related to their harpoons, formed of the hard and heavy 
wood of the macana palm tree, answered guaike, guaike, which signifies pointed pole." I

This was written by Humboldt during his sojourn in Cumana in I 802 , and it is interesting to note that the Guaiqueria tribe today lives in the same localities it inhabited then and that it has neither spread nor diminished. Codazzi, in I84I, also states that the language of the Guaiqueria has been totally forgotten, but that it originally was a dialect of the Guaraunos. ${ }^{2}$

\section{HistORY}

The early history of the island of Margarita is closely allied to that of the neighboring island of Cubagua (see map, fig. I). When Columbus coasted the peninsula of Paria on his third voyage, he passed the islands of Margarita, Cubagua, and Coche on July 3 I, I 498, and, strangely enough, named the first of these islands Margarita (the word margarita in Latin and Spanish signifies "pear]"), although he knew nothing of the pearls that were found in the surrounding waters. ${ }^{3}$ True, he met an Indian on the following day who was in possession of pearls that excited the rapacity of the soldiers accompanying the Admiral, but this would not indicate that he was aequainted with the presence of pearl-beds when he named the island.

The first settlement of Cubagua took place about I500, when some fifty adventurers sailed from Hispaniola to exploit the pearl fisheries. ${ }^{4}$ These adventurers were obliged to go to the mainland to acquire Indians for work on the pearling grounds, and by their wanton cruelty undid much of the good work that was being conducted by the Franciscan friars settled at Cumana. There can be no doubt that the pearl fisheries must have been highly productive in those times, as the Spaniards in some instances paid as much as I50 ducats each for the Lucayan Indians who were captured in the

1 Alexander von Humboldt, Personal Narrative, 3 d ed., London, I822, vol. II, pp. I9I-I92.

${ }^{2}$ Agustin Codazzi, Resumen de la Geografia de V'enezuela, Paris, 1841, p. 249.

${ }^{3}$ Gonzalo de Oviedo, Historia General y Natural de las Indias, Madrid, I85I, lib. xix, cap. $\mathrm{I}$.

${ }^{4}$ Leonard V. Dalton, Venezuela, New York, I912, pp. 65, 67 et seq. 
Bahamas and transported to Cubagua on account of their skill as divers. ${ }^{1}$ In fact, the fisheries were the cause of the total annihilation of the aborigines of the Bahamas. The Cubaguan settlers found, however, that the tribes inhabiting Margarita were too warlike and too well versed in the use of offensive weapons to submit to capture, ${ }^{2}$ consequently the Margarita Indians were left alone. As a result, La Asunción on Margarita was not founded until I524, whereas Nueva Cadiz on Cubagua had been raised to the dignity of selfgovernment in I52 I and was an important town long before that time. It may serve as an illustration of the strength of the Margarita tribes to state that the early settlers lived on Cubagua, a flat, barren island, with no trees whatsoever, where no water was found, and whence the inhabitants had to send to Cumana for all food supplies and drinking water, when they would have been in as close proximity to the pearling grounds had they lived on Margarita where living conditions, while not good, were infinitely superior to those prevailing on Cubagua. Again we read ${ }^{3}$ that when Marcelo de Villalobos went to Margarita to colonize and to exploit the resources of the island, he proposed to the King of Spain the building of a fort for defence against the Indians who were "Carib and warlike." The writer's archeological researches, as will be shown, do not indicate that the remains found on Margarita resemble those of the Carib from the Lesser Antilles, and it may well be that Herrera used the name Carib merely to classify the Margarita tribes as different from the other peaceful Indians met by the conquerors in the West Indies. However, in the excavations on the island there was found a quantity of human bones that had been split in order to abstract the marrow, but whether these bones were of the Guaiqueria victims of Carib raids or were the remains of cannibal feasts of the Guaiqueria themselves, could not be determined. But it is more than likely that these split bones are evidences of a Carib raid and had been left by the invaders on the sites of the destroyed Guaiqueria villages, for we find that the native inhabitants at a later time pleaded with Alonso de Ojeda for aid against the Carib

1 Antonio de Herrera, Hisloria General, Madrid, I730, dec. I, book viI, chap. Ix.

${ }^{2}$ Dalton, op. cit., pp. 69-70.

${ }^{3}$ Herrera, op. cit., dec. III, book vir, chap. II. 
of the Lesser Antilles, saying that they suffered greatly from their depredations. Ojeda in consequence went to Dominica and Guadeloupe on a punitive expedition against the inhabitants. ${ }^{1}$ Later in his work Herrera contradicts his statement that the Guaiqueria Indians were Carib when he quotes Rodrigo de Figueroa, "all Indians of these islands were Caribs excepting those of the Lucayos, Trinidad, Barbados, Gigantes, and Margarita." 2

Nevertheless, even if the Guaiqueria were afraid of their Carib neighbors to the eastward, the Spaniards who settled on Margarita did not find it an easy task to subjugate the aborigines of the island. Benzoni wrote in I5 1 I that he arrived on Cubagua and there met Pedro de Herrera, governor of the island of Margarita, who was on his way to Terra Firma, with two brigs and thirty Spaniards, there to get some slaves. ${ }^{3}$ Had Herrera found it easy to use the native inhabitants of his own colony, conscientious scruples would not have deterred him from enslaving them. And it is probably due to the warlike tendencies of the Guaiqueria that they did not suffer the same fate as the other native tribes of the Antilles; moreover, "they enjoy several privileges, because from the earliest times of the conquest they remained faithful friends to the Castilians. The King of Spain names them in his public acts, 'his dear, noble, and loyal Guayquerias." "4 In consequence there is today a large proportion of pure Guaiqueria blood on the island of Margarita, and especially on the northern coast in the villages of San José de Paraguachi and Juan Griego. Humboldt also states that "next to the Caribs of Spanish Guyana, it is the finest race of men on Terra Firma," meaning the inhabitants of the suburbs of Cumana as well as those of Margarita. This is in strange contrast to the illadvised statement of Scruggs, who, on hearsay, says, "The inhabitants are exceptionally indolent, stupid, unenterprising and improvident," 5 a description with which the present writer can by

${ }^{1}$ Herrera, op. cit., dec. I, book IV, chap. II.

2 Ibid., dec. II, book $\mathrm{x}$, chap. $\mathrm{v}$.

${ }^{3}$ Girolamo Benzoni, History of the New World, Rear-Admiral Smyth's transl., Hakluyt Society Publications, London, I857. p. 3.

${ }^{4}$ Humboldt, op. cit., vol. II, p. 44.

${ }_{5}^{5}$ William L. Scruggs, The Colombian and Venezuelan Republics, Boston, Igro, p. 201 . 
no means agree, as he found the inhabitants of Margarita-both the original Guaiquerias and the Spanish-Americans-to be particularly industrious. Owing to the absence of rivers, Margarita is bleak and barren, and hence the inhabitants are impoverished, a condition especially apparent since the pearl fisheries are no longer very productive. Altogether the Margariteños are a far more industrious class of people than is generally found in the West Indies.

It is likely that the settlements on Margarita received important accessions when Nueva Cadiz on Cubagua was completely destroyed by earthquake and a tidal wave in $\mathbf{1 5 4 3}$. The Royal Treasury was kept on Margarita after the year named, and on one occasion, in I 56r, was robbed by Lope de Aguirre, ${ }^{1}$ a traitor to the Spanish Crown, after whom a small settlement on Margarita at the place where Aguirre made his landing is still called El Tirano. ${ }^{2}$ In fact, this region became of such strategic and commercial importance that the island of Coche, between Margarita and the mainland, where salt deposits are found, was sacked by the English expedition under Captains Amias Preston and George Somers in 1595, and the settlements on Margarita were destroyed by the Dutch in $1662 .^{3}$

It was probably soon after the latter event that the island lost its first importance, although the pearl fisheries had long since been exhausted owing to indiscriminate fishing even during the spawning seasons. There was never enough soil on the island to permit sufficient agriculture for the support of a considerable population, hence during the next century and a half, although continued as a Spanish province, Margarita was not of commercial importance and it did not figure largely in the annals of history. The island came into prominence again from 1813 until 18 I 8 when it heroically defended itself against the greatly superior Spanish forces sent to wrest from the revolutionists their newly-declared independence. Undoubtedly the most heroic figure in this struggle of the piti-

${ }_{1}^{1}$ Andrés A. Level, Esbozos de Venezuela, Primer Esbozo: La Margarila, Caracas, r 88 r, p. 69.

2 Ibid., p. Ivii.

${ }^{3}$ Codazzi, op. cit., p. 598. 
fully small forces of the Margariteños against overwhelming odds was Doña Luisa Caceres de Arismendi, wife of Colonel Juan Bautista Arismendi, one of the leaders in the revolutionary movement. Margarita was captured by Morillo in 1815 , but was in revolt again the next year, after the Spanish officers had broken their pledges of amnesty. Simon Bolivar, the great revolutionary leader and founder of five South American republics, visited the island in $18 \mathrm{I} 6$ and held a conference with the revolutionary chiefs in the Pueblo de Santa Ana, now known as El Norte. The island was again invaded by the Spaniards on July I 7, I 817 , but despite their superior numbers they were signally defeated by the insurgent forces and finally compelled to evacuate the island a month later. ${ }^{1}$

\section{Physical Features}

Mention is made by the earliest historians that Margarita lacked a suitable supply of water. Herrera wrote that the island "does not have an abundance of water, although it is fertile of grass for cattle." 2 Depons mentions that "the nature of its soil condemned it to be forever a languishing establishment. Instead of vegetative earth, it is covered with a sandy surface nearly a foot in depth, mixed with hollow and rotten madrepores. Cultivation holds out no hopes." 3 Scruggs states that "the first view of the island from the sea is one of matchless beauty, but it will hardly bear closer acquaintance. The soil is arid and non-productive." 4 Speaking in general, the writer found these statements to be true; indeed it would be hard to describe the desolate appearance of the greater part of the island. In those places where various cacti are not the prevalent growth, one sees large sandy savannas covered with dry and scrubby broom-grass, with here and there a stunted tree that seems to find the struggle for life almost too great for endurance. In other parts the soil consists of indurated clay covered with decomposing micaceous rock. The roads are bare stretches of sand,

${ }^{1}$ Level, op. cit., p. xxi.

${ }^{2}$ Herrera, op. cit., Description, vol. I, chap. vir.

${ }^{3} \mathrm{~F}$. Depons, A Voyage to the Eastern Part of Terra Firma or the Spanish Main, New York, I806, vol. III, pp. 172-173.

${ }^{4}$ Scruggs, op. cit., p. 201. 
with not a tree to temper the glare of the tropical sun. The progress on these roads through dust a foot deep is indescribably difficult.

One can say that there are no rivers on the island, although there are three stream-beds that give promise of filling during the rainy season. The springs of these former rivers have been piped to large reservoirs in the mountains, which in turn supply water to the towns of El Valle, Porlamar, and Pampatar. Even thus, the supply is uncertain and scant under the best conditions. It is possible that in pre-Columbian times the rainfall was somewhat greater, but that it diminished after the Spanish conquest when the mountains were denuded of their timber. From the geological structure of the mountains, however, it would appear that even in early times large parts of the island presented the same bleak and arid appearance that they do today. One is especially impressed by the lack of vegetation on the hill-slopes and the consequent failure of the hills and mountains to store the rainfall.

Archeological Investigations

Unlike some of the other West India islands, where large aboriginal shell-deposits are found, the greater part of the investigation on Margarita was confined necessarily to surface work. The writer has already mentioned the scarcity of soil suitable for cultivation. In consequence of this, with the exception of some artifacts found on a small village-site in the northern part of the island, the entire Margarita collection consists of "surface-finds." These superficial investigations necessitated visiting all settlements in order to make inquiry among the natives with a view of learn'ng whether they possessed any Indian objects. The Margariteños, and especially the women and children who go about gathering firewood, are remarkably keen-sighted, readily perceiving any foreign object lying on the ground, hence one may find carefully guarded stone axes and petaloid celts in many of the native huts. These people attribute the usual supernatural properties to objects of this kind, superstititions that do not differ materially from those previously described by the writer. ${ }^{1}$ Unlike the inhabitants of some of the other

${ }^{1}$ T. de Booy, "Certain West-Indian Superstitions Pertaining to Celts," Journal of American Folk-Lore, vol. Xxvirr, Jan.-Mar. I9I5, pp. 78-82, and Contributions from the Museum of the American Indian (Heye Foundation), vol. Ir, no. 3, I9I 5. 
islands, they appear to be more willing to dispose of these stones at prices far from exorbitant; in fact, in some instances the stones were freely given.

Stone artifacts were collected in practically all parts of Marga-

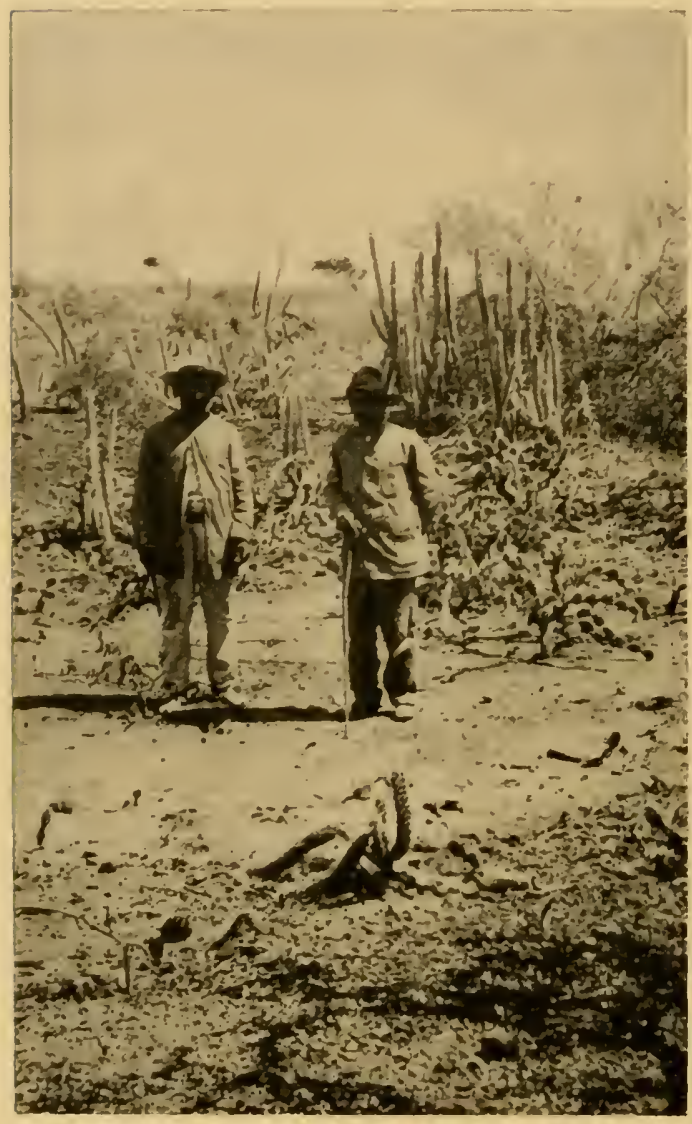

FIG. 2.-An artificial reservoir at San Antonio. rita, but it was especially on the southern coast, in the San Antonio region, that potsherds were found. Of all parts of Margarita, excepting Macanao, San Antonio perhaps presents the bleakest appearance, and one cannot observe even the smallest cultivated patch of ground. The inhabitants eke out a livelihood by raising goats, and in making charcoal from the small trees which they cut from the hillslopes. They also cure large quantities of fish, and hire themselves as pearl-fishers. The only vegetation seen on the plains of San Antonio is cacti, impenetrable in places and of several varieties. Scattered among this growth one often finds sherds of aboriginal pottery, the only indication of the sites of former villages. Patient and laborious search rewards the investigator with little of consequence, however, for during the lapse of centuries the comparatively brittle earthenware has become greatly disintegrated. 
The native guides were especially emphatic in their assurance that a large number of shallow depressions found in this part of the island were due to excavations by the pre-Columbian aborigines for the purpose of catching and preserving rainwater, and the writer is inclined to believe that their statements are correct. The reservoir shown in figure 2 has the appearance of the slope of a small hill; but by drawing an imaginary line across the shoulders of the two guides and continuing it circularly through the more highly lighted part of the picture, in the foreground, through the cactus plant, one may gain an idea of a depression of this kind. The reservoirs have a uniform depth of approximately 6 feet, with a diameter of 20 feet at the bottom and about 65 feet at the top. In some instances the soil from the excavation may still be seen around the top, as if p'aced there to heighten the receptacle; but in most cases this surrounding mound has become obliterated. The guides called these structures "arroyos," the Spanish term for gullies.

Mosquito Point, also on the southern coast of Margarita, seems to have been a favorite abode of the aborigines. The scenery here differs but little from that of San Antonio, although the small sand-dunes bordering the shore give it an even more desolate appearance. The coast here is ideally adapted to the needs of a fisherman, and it would be an easy matter to launch canoes and to haul them asho:e. One cannot, however, give an adequate impression of the heat of these localities: the intense radiation from the sand and the stones, and the total lack of shade, must have made life here a burden indeed. It is on these shores that large deposits of the shells of the pearl-mollusk (Meleagrina margaritifera) are found. The writer partly excavated a few of these, but was not successful in uncovering artifacts of any description. These excavations were not difficult, for while the soil immediately back of the shore is as hard as that farther inland, the shell deposits are found only on the dunes that fringe the sea. In one of these excavations a clearly defined layer of ashes extending through the shell deposit was exposed, and while the reason for making a fire on top of the shells during the growth of the heap is not known, excavation did not afford evidence to warrant the assertion that the 
shell deposit was of aboriginal origin. These shell-heaps therefore can be explained only by the belief that they resulted from early Spanish pearl fisheries. They differ from the modern shell-heaps made on the island today, in that the shells have become mixed with the drifting sand of the shore and that they have lost their luster through long exposure to the elements.

Unlike so many of the IVest India islands, caves are not found on Margarita, owing to the absence of coralline limestone. The

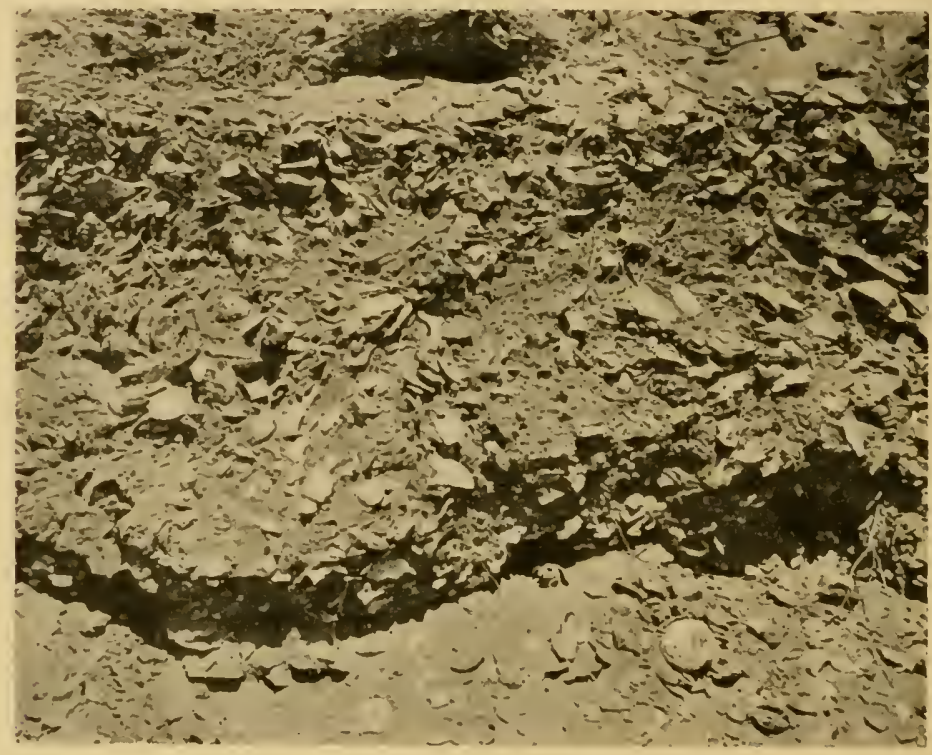

FIG. 3.-Shell deposit at Mosquito Point.

only limestone outcrop on the island is Mount Macuspo, four miles east of Laguna Chica, the whiteness of which, in strong contrast to the brownstone Cerro de la Vega, makes it visible from afar. Isla Blanca, a small cayo, or key, eastward from Moreno Point, is also of limestone formation, but guano-hunters who have visited it informed the writer that it contains no caves. A trip was made to Mount Macuspo and careful search conducted both at the foot and throughout the slopes in the hope of finding caves, but none were discovered. 
Another region in which a number of artifacts was found is the mountainous district of La Sierra. It is here that practically all the agriculture of the island is conducted, and this is by far its most attractive part. It is certain that the shore-dwelling aborigines came here for their cassava harvest, and more than likely that here also they made their cassava bread, judging from the number of griddle fragments found in the vicinity. No kitchen-middens and no shell deposits were found, although shells scattered here and there indicated that the aborigines ate sea-food even in the interior of the island. Mention should here be made of the finding of four massive stone mortars, but no other artifacts, within a hundred yards of a small mountain spring in this district.

A fairly large number of shells and sherds were found on a bleak hillside in the mountain range between El Valle and Asunción. This hill has a very pointed crest, and the slope on which the remains were found has an angle of almost 60 degrees, which makes its use as a village-site rather remarkable. Were the summit of the hill a plateau large enough to afford space for a couple of huts, one might assume that the shells and other remains found on the slope had been washed there by rain; but the contrary being the case, no suggestion of a reason for the occurrence of the objects referred to on the slope can be offered.

The largest shell deposits, and those that showed unquestionable evidence of pre-Columbian occupancy, were discovered near the village of San José de Paraguachi. The dry bed of the Rio Viejo, about 8 feet deep and $x 2$ feet wide, which fills during the rainy season and originates on the slopes of the Traga Plata mountain, whence it winds its way through an enclosed valley to the sea, passes through a subdivision of San José de Paraguachi, called Giri-gire. It is probable that Giri-gire was the native designation of the aboriginal village on this site, and that it has been preserved and transmitted by the Guaiqueria Indians still living in the neighborhood. The river-bed is the dividing-line of two properties, owned respectively by Señora Prudencia Carajalvo and Señor Madeira, the latter property being known as "La Estancia." On both banks kitchenmiddens were found. A large field on the eastern side of the river, 
the Caravaljo property, was not under cultivation during the writer's visit, but sugar-cane and cassava had been planted there at one time. There was no superficial evidence of the prehistoric occupancy of the village-site in this field, aside from some sherds and shells lying here and there, and the middens on the same side

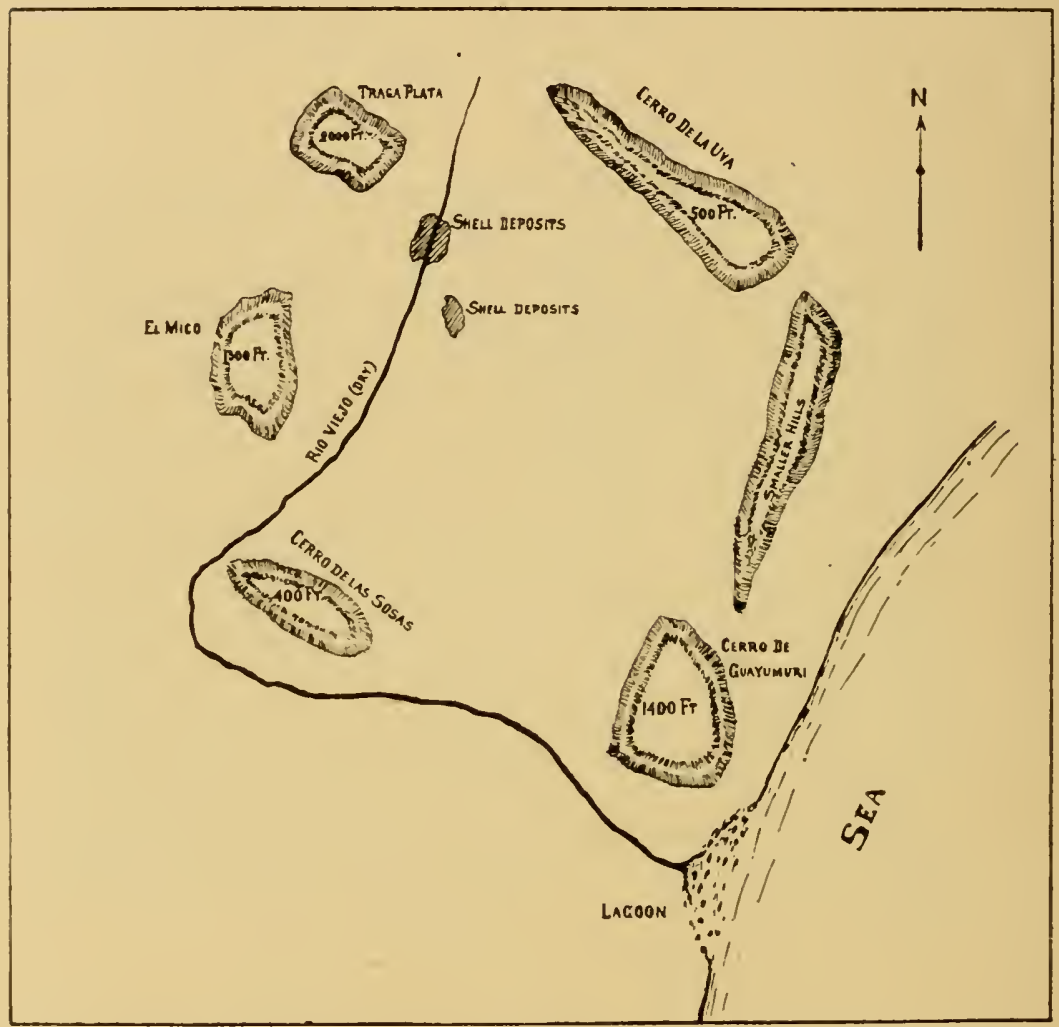

FIG. 4.-Situation of the Giri-gire kitchen-middens. (The map is not drawn to scale.)

of the stream-bed had no definable contour, consequently it was necessary to determine the extent of these remains by means of test-holes.

The middens on the western bank of the river-bed were likewise investigated, but in appearance they did not differ from those on the opposite side. The village-site extends for about half a mile along each bank, and is not more than a quarter of a mile in 
width. It consists of individual deposits about 60 feet in diameter, which merge into one another. There are two or three middens in the large field of Señora Caravaljo, about three hundred yards from the river-bank above referred to. This site is not more than two miles and a half from the sea, but by following the mountain path it is about five miles from El Tirano, the nearest seaport.

The shell deposits of Giri-gire are covered by about a foot of diluvial deposit. There are no clearly defined layers of shells and ashes, all being mixed together, with an occasional sherd or other artifact. This mixture does not exceed a foot in depth, and in many instances it is even less. Very few stones were found with the midden débris, nor were bones p'entiful. The deposit was so compact that shells, ashes, charcoal, bones, and artifacts adhered together in large, hard lumps. It is noteworthy that no fragments of the clay griddles, such as are found so generally throughout the West Indies, occurred in these deposits, although many such fragments were collected in other parts of Margarita. This absence of griddle fragments from the Giri-gire middens, however, is not necessarily an indication that the site was occupied by Indians of a culture distinct from that of the aboriginal occupants of sites in other parts of the island; for the two-pointed stones, later to be mentioned, which appear to be typical of the pre-Columbian inhabitants of Margarita, were found in large numbers on the Girigire site as well as in other parts of the island.

A number of fragments of human bones, almost invariably split as if to abstract the marrow, were found. As above pointed out, the writer believes that these bones are the evidences of a raid on the Guaiqueria by Carib from the islands to the eastward, who held their cannibal feast on the site of the destroyed village of their victims.

The writer is indebted to Mr L. P. Gratacap, of the American Museum of Natural History, for the identification of the following sea-shells found in the Giri gire kitchen-middens. It will be noted that about ninety-five per cent. of the shells are of one species and possibly four per cent. of another, while the remainder were found in extremely small numbers. 


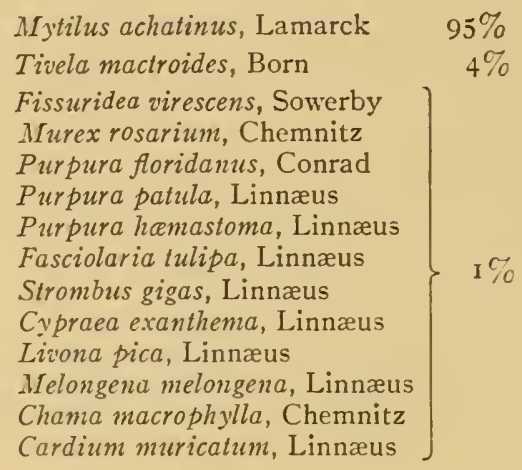

Besides these shells, some barnacles and many stems of madrepore coral were found.

In addition to the human bones, a number of bones of lower mammals were found, some of which were kindly identified by $\mathrm{Dr}$ F. A. Lucas, Director of the American Museum of Natural History. The identified bones are those of the peccary (Pecari sp.) and the deer (Odocoi!eus sp.). Turtle-bones also were found, and some bones that resembled those of birds, although the identification of these is uncertain. Besides the above, some skeletal remains of fish, amongst which are those of the bluefish (Pomatomus saltatrix), were recovered.

\section{The Collections}

While a large number of pottery fragments were found in Margarita, the writer was successful in obtaining only two entire vessels of pre-Columbian origin. These are shown in plate $\mathrm{r}$. Of the two, $a$ was brought by a woman who said it had been discovered by her son while cutting firewood on top of one of the mountains bordering Cerro de la Vega. A subsequent visit to this locality resulted in finding many sherds, but no more entire vessels. The receptacle is of dark-brown ware, about a quarter of an inch thick. It stands 5 inches high, and the diameter of the mouth is 4 inches. An inspection of the sherds from the island indicates that this type of small pitcher was not uncommon.

The other entire ressel (pl. I, $b$ ) is of a type entirely foreign to either the West Indies or the adjacent mainland of South America. 

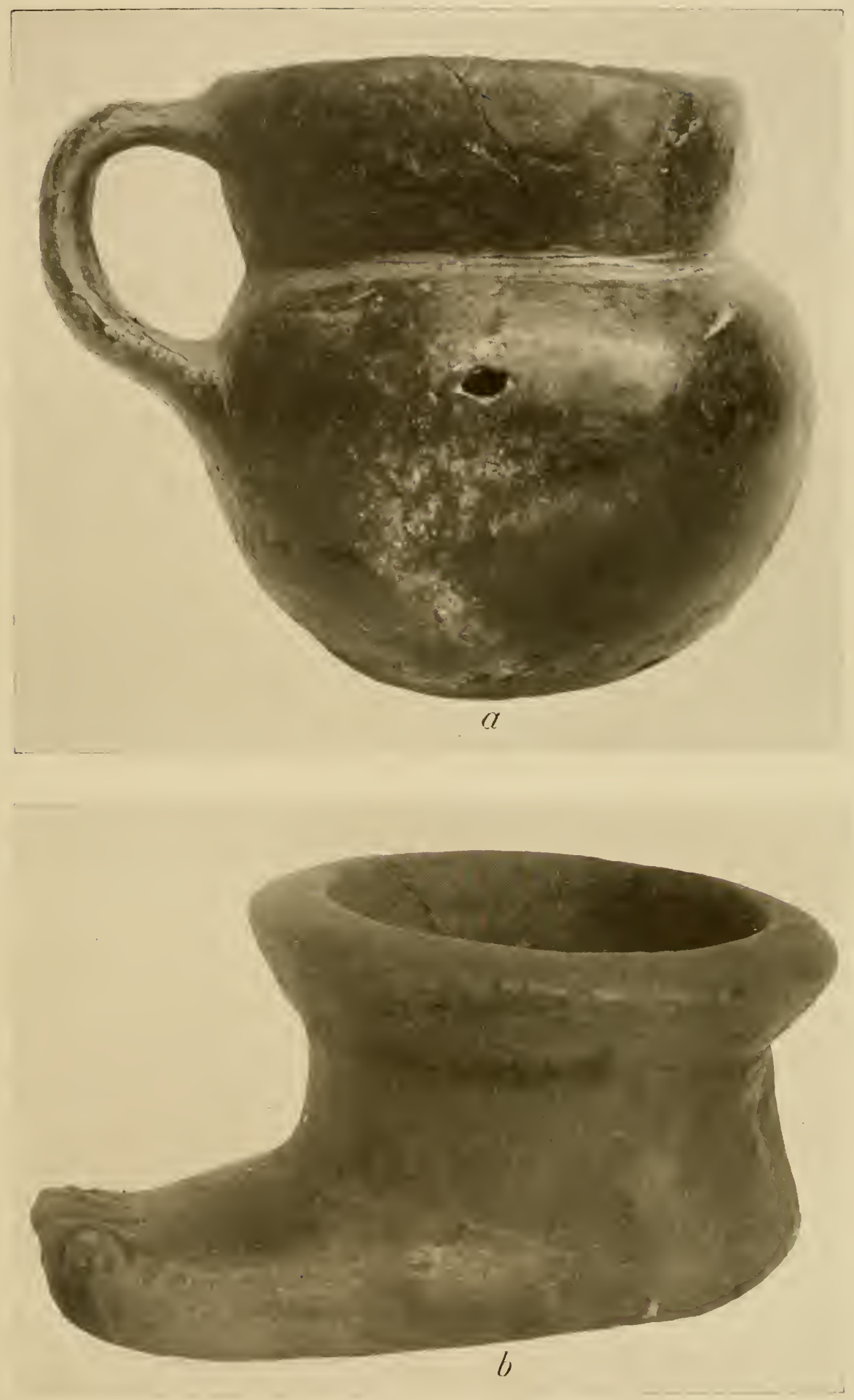

PREHISTORIC POTTERY VESSELS 

It stands $21 / 4$ inches high, is $4 \frac{1}{2}$ inches long at the base, and $31 / 4$ inches in diameter at the mouth. The inside depth of the vessel is almost 2 inches. This "foot-jar" of heavy, dark-brown pottery, is well modeled, the five toes with their nails and the ankle of the foot being clearly represented. No other sherds that indicate the existence of other vessels of this type were found. The foot-jar was found in excavating one of the Giri-gire kitchen-middens. Although far superior in design, in type it resembles the foot-jars from Oaxaca, Mexico.

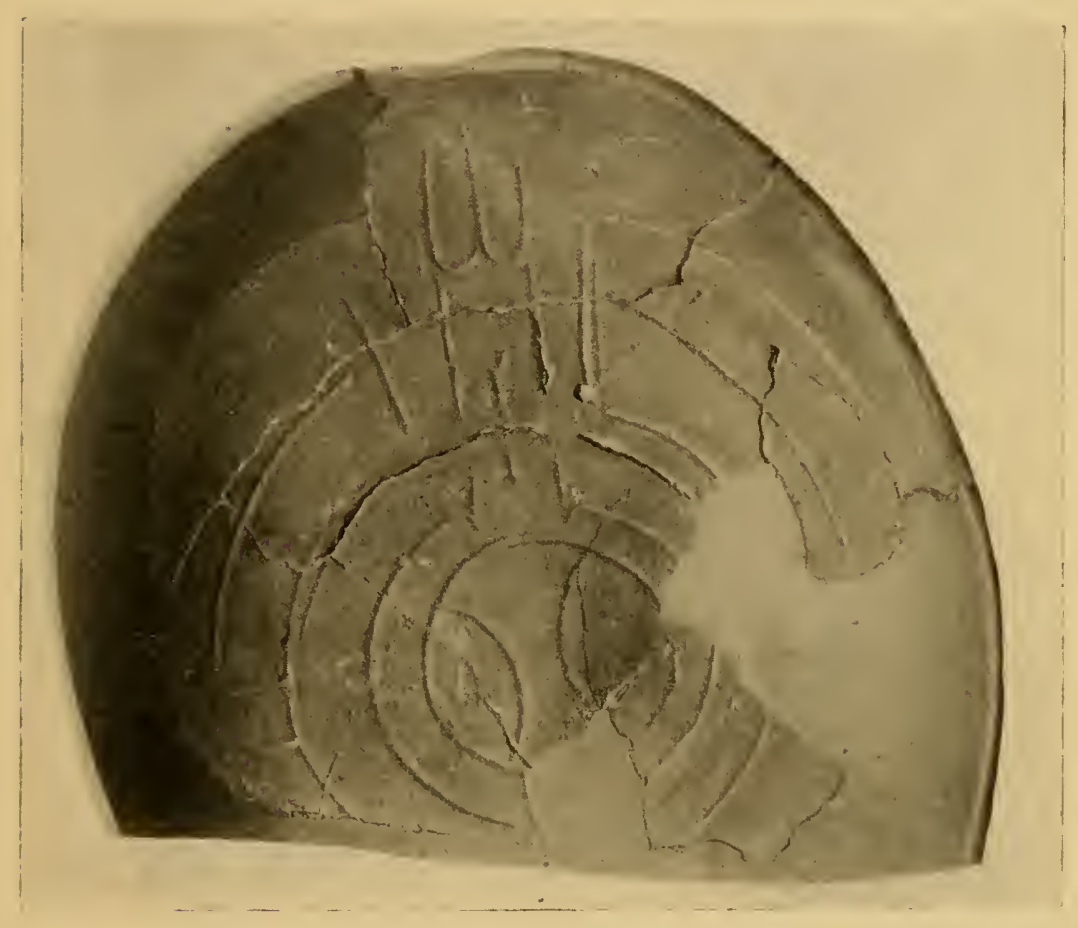

FIG. 5.-Shallow bowl from a Giri-gire kitchen-midden.

From fragments found, the vessel shown in figure 5 was partly reconstructed. This shallow, elliptical bowl, which originally had a length of II inches, a width of 8 inches, and stood 2 inches high, is made of dark-gray ware of a thickness of three-sixteenths of an inch: The outer surface is plain, but the interior is decorated with 
shallow, incised, circular lines. The fragments of this specimen were recovered from one of the Giri-gire middens.

Excavation in the Giri-gire middens produced also a number of pottery heads similar to those from the West Indies, and also more or less allied in type to some of the heads collected by Dr Fewkes at Erin Bay, Trinidad. ${ }^{1}$ It should be noted that most of the heads illustrated by Dr Fewkes are painted, while the Giri-gire examples do not now indicate painted decoration, although it may be that originally they were so ornamented. A close comparison of head $c$ of our plate II with head $f$ shown in plate xvil of Dr Fewkes' article, and of heads $e$ and $f$ of plate II of the present paper with heads $c$ and $e$ of plate XIX of Dr Fewkes' paper, will reveal this similarity. The writer recovered by excavation a large number of pottery heads on the St Bernard estate near Cape Mayaro, Trinidad, where he spent four months in archeological research after the termination of the Margarita work, and these show even greater similarity to the Margarita specimens. ${ }^{2}$

Little information can be given in regard to the other heads illustrated in plate II. Often the identification of such pottery heads as representing certain animal forms appears to be fanciful. More than likely $b$ and $f$ represent human heads, while $e$ may be supposed to have been intended to portray the head of a bat.

The manner in which these heads served as handles for the vessels to which they were attached is shown in plate II, $h$. Frequently the heads are hollow and served as rattles, containing a number of clay pellets. Another type of handle is shown in plate II, $g$, of which a number of examples were found. Plate II, $a$, exhibits one of the supports of a vessel, shaped in the form of a human foot, with incised lines representing the toes. The ankle is clearly shown.

The majority of sherds found throughout Margarita indicate that the typical vessel was severely plain, having indeed no decoration whatsoever. It may of course be possible that the surface of

${ }^{1}$ J. Walter Fewkes, "Prehistoric Objects from a Shell-heap at Erin Bay, Trinidad," American Anthropologist, N. S., vol. XVI, no. 2, April-June I9I4, pp. 200-22I; also in Contributions from the Heye Museum, vol. I, no. 7, I9I4.

2 The writer hopes to publish the results of his researches in Trinidad in the near future and to incorporate a detailed account of this similarity. 

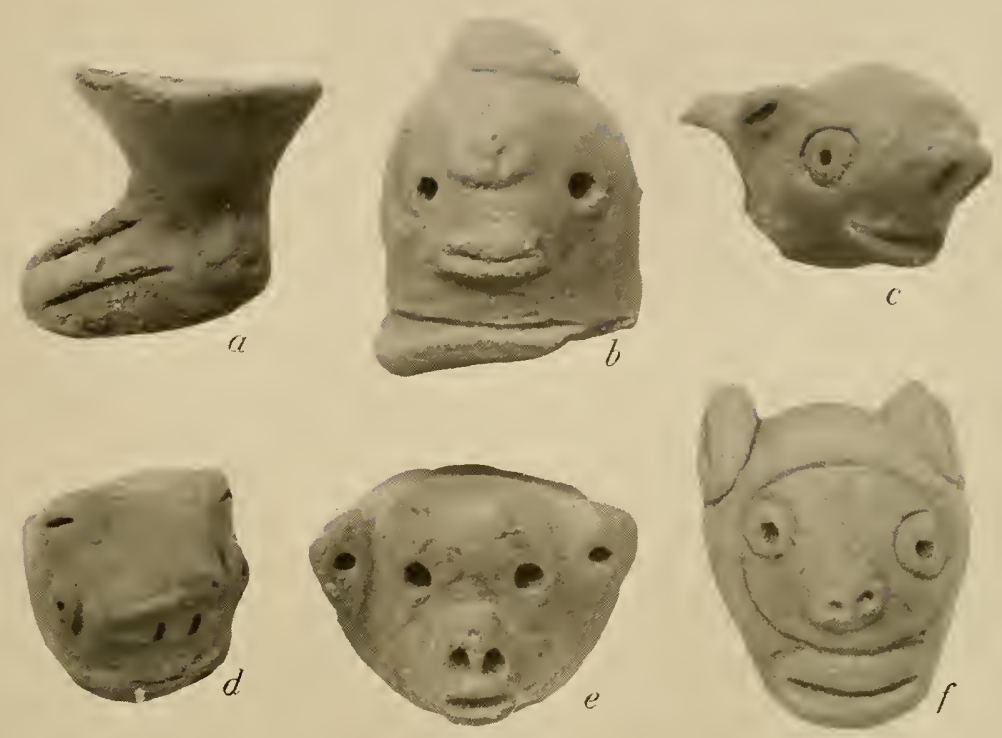

HEADS OF POTTERY
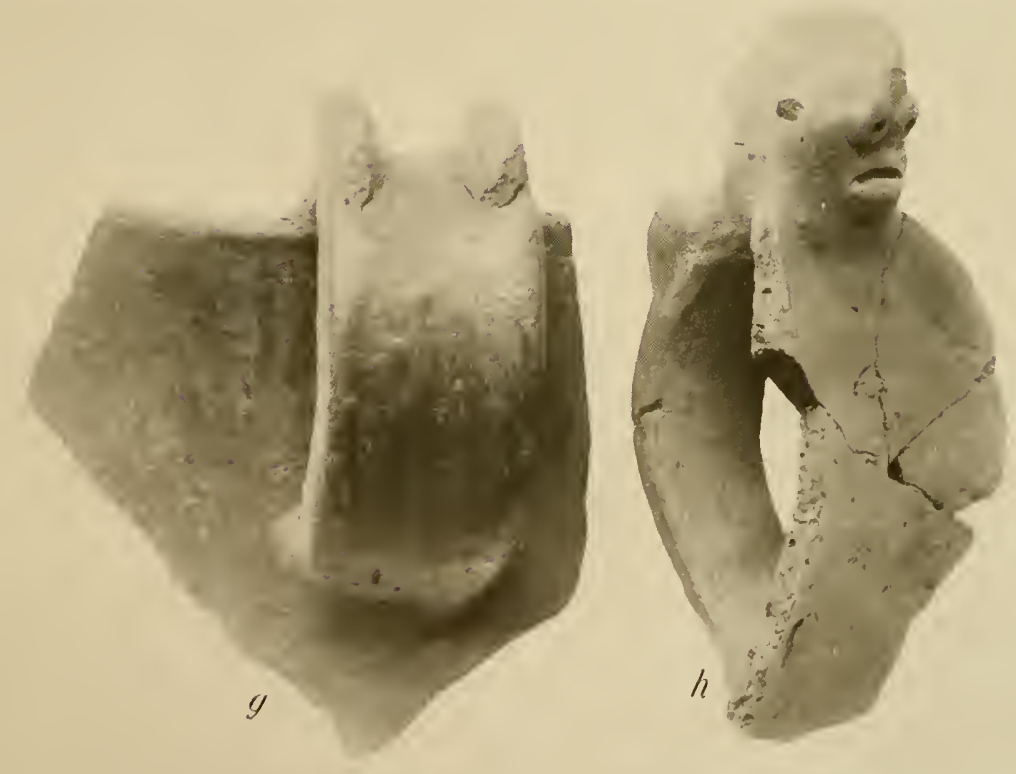

HANDLES OF POTTERY 

some of the vessels was decorated with painted designs, but that exposure to the elements has caused their disappearance. The usual incised lines with a small impressed pit at their extremities were found in no instance. Figure 6 illustrates three sherds which may

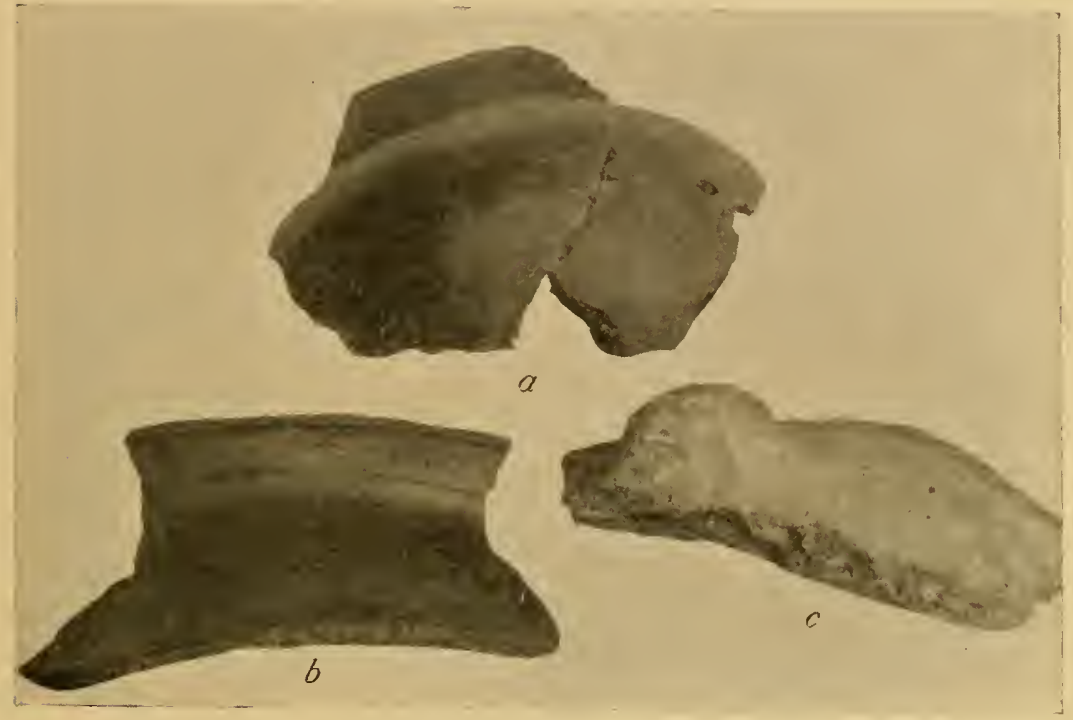

FIG. 6.-Potsherds.

be regarded as typical of all specimens of this kind collected. Of these, $a$ is a fragment of a globular vessel with a perpendicular rim; $b$, a fragment of a larger vessel with a diameter of about 16 inches and a height of about I 2 inches, and with a slightly outcurving rim; $c$ is of a different kind of pottery, the clay of which was plentifully tempered with minute stone chips and crushed shell. It will be noted that this fragment is far thicker than the others. Probably half of all the sherds found were of this kind of ware. The vessels made of this seem to have had straight sides, and, surrounding the rim, frequently had small lugs of the same kind as the one shown in specimen $c$.

Three fragments of vessels (fig. 7) were found in the Giri-gire kitchen-middens that were colored with red, white, and brown pigment, applied to the ware before firing. Probably six hundred 
sherds entirely similar to these were found in the middens on the St Bernard estate in Trinidad, suggesting that the Carib raiders previously mentioned left some of their pottery on the site they had destroyed. This suggestion is well worthy of consideration when it is remembered that other sherds of exactly the same kind of pottery have been found on some of the Carib islands, as Carriacou and St Vincent, and are now in the Museum of the American Indian. Sherds of this variety have not been found anywhere in Trinidad, however, except in the middens near Cape Mayaro.

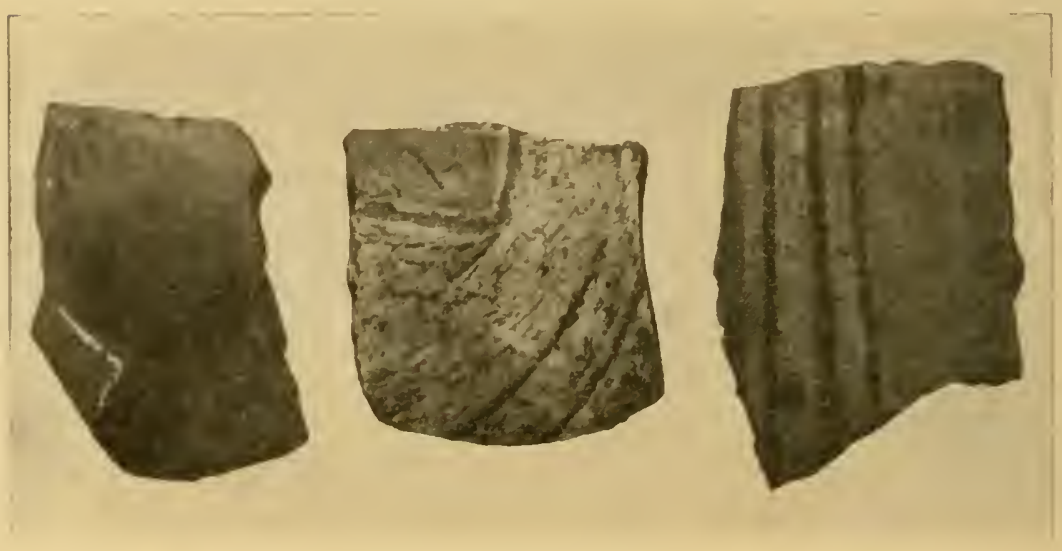

FIG. 7.-Sherds of painted pottery.

The writer figured a fragment of a clay griddle from Jamaica in a previous article on the archeology of that island, ${ }^{\mathrm{I}}$ and in another paper $^{2}$ mentioned a similar discovery in Santo Domingo. Clay griddles were found likewise in Margarita (fig. 8), and a considerable number of fragments were collected on that island. These do not differ in any respect from the sherds in the collections of the Museum of the American Indian from Cuba, Jamaica, Santo Domingo, Trinidad, and several of the Lesser Antilles. It is interesting to

1 "Certain Kitchen-middens in Jamaica," American Anthropologist, x. S., vol. xv, no. 3, July-Sept. I9r3, p. 434; also in Contributions from the Heye Museum, vol. I, no. 3 , I913.

2 "Pottery from Certain Caves in Eastern Santo Domingo," ibid., vol. xvir, no. I, Jan.-Mar. 1915 , p. 94; also in Contributions from the Heye Museum, vol. I, no. 9. I9I5. 

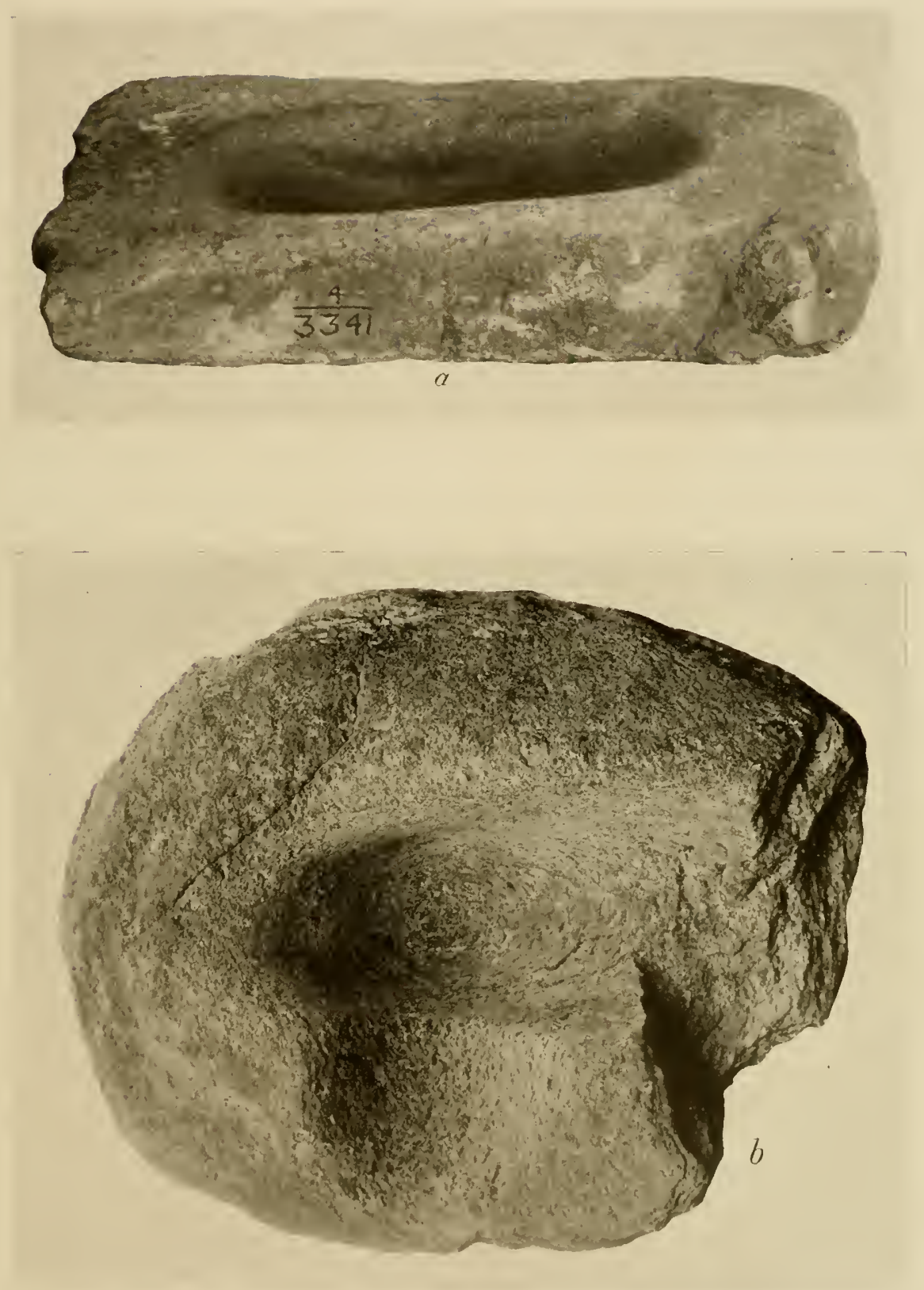

STONE MORTARS 

note the general distribution of this type of artifacts throughout the islands, regardless of whether they were inhabited by the Carib or the Arawak.

A number of massive mortars were found in Margarita, two of which are illustrated in plate III. The first and largest specimen (a) is 25 inches long, $I_{3}$ inches wide, and averages $51 / 2$ inches in height. The cavity, as in all the Margarita mortars, is elongate.

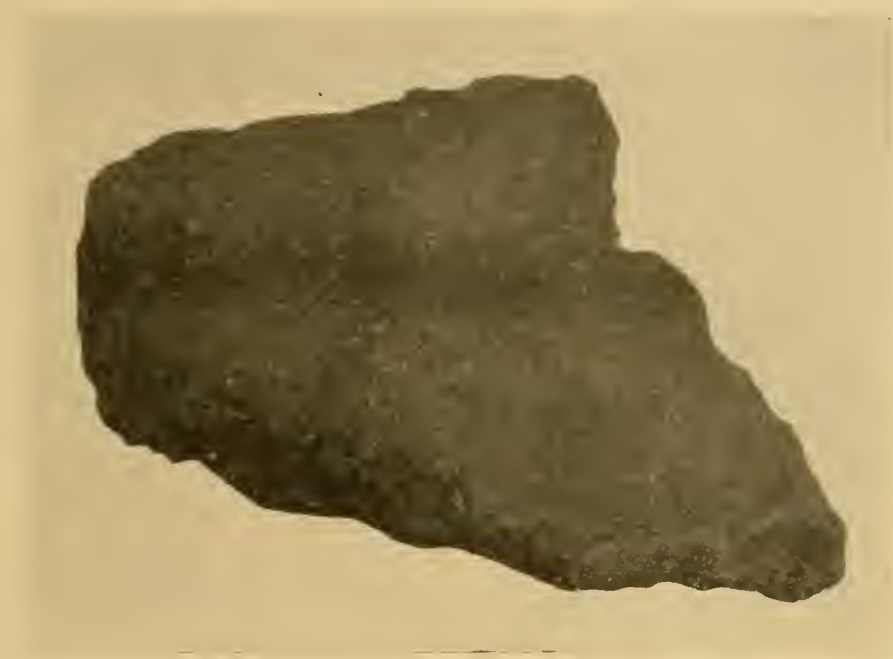

FIG. 8.-Fragment of a clay griddle.

Specimen $b$ is much smaller and more disc-shaped; its length is 16 inches, width II $1 / 2$ inches, and average height 3 inches. The cavity is elongate, as in the others, and the commencement of another cavity, at a right angle to the first, can be seen. With many of these mortars were found handstones, of which three are shown in figure 9. The grinding surface of these stones is flattened, while the side which was held in the hand is convex. The length of the examples here shown is 6 inches, although a number were collected that are about an inch longer. A considerable number of handstones were found throughout the island.

To the present time, there is no authentic record of the finding of a single chipped arrowpoint in the West Indies. The writer therefore 
was greatly interested in acquiring from Margarita the chipped quartzite arrowpoint, an inch and a quarter in length, shown in figure Io. No similar specimens were discovered, although one or two chipped flints were found. That the Guaiqueria Indians used

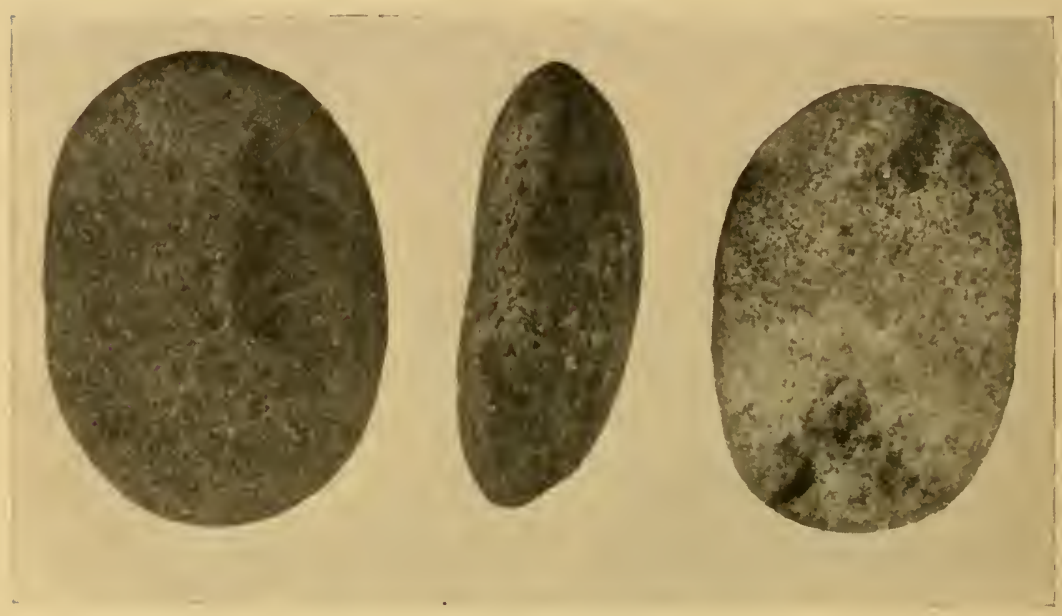

F1G. 9.- - Handstones.

harpoons or arrows is proved by their name, derived from guaike, meaning "pointed pole," as already mentioned. Furthermore, the writer acquired two arrowshaft rubbers on the island: these are

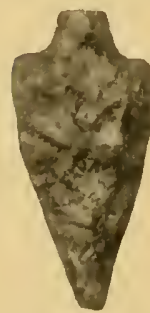

FIG. IO.-

Ch i p ped quartzite arrowpoint. illustrated in figure $\mathbf{I}$. The tip of the arrowpoint shown in the illustration is broken off, and the point itself is in no sense remarkable. Nevertheless, the value of this unique specimen is evident, and it would be interesting to know whether similar chipped points exist on the adjacent mainland. The two rubbers referred to are of coarse-grained stone and are not unlike specimens from the United States. ${ }^{1}$ The Guaiqueria Indian probably tipped his arrow with the poisonous spine of the sting-ray, which is still used extensively for the same purpose by the primitive tribes on the northern coast of South America.

1 "Handbook of American Indians," Bulletin 30, Bureau of American Ethnology, Washington, 1907, pt. I, p. 92. 


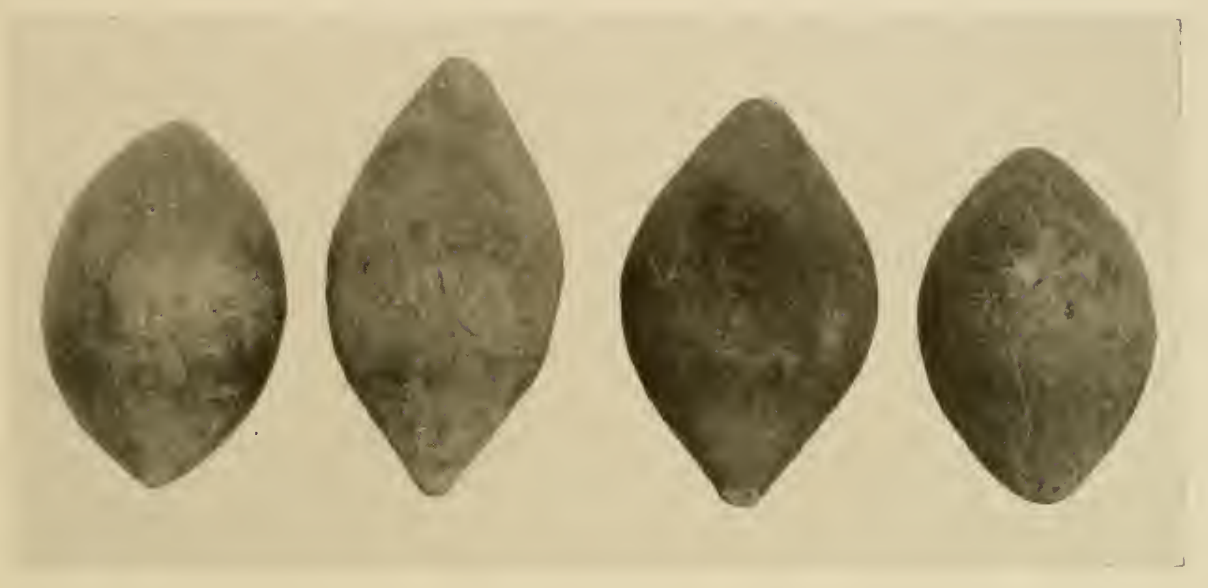

TWO-POINTED OBJECTS
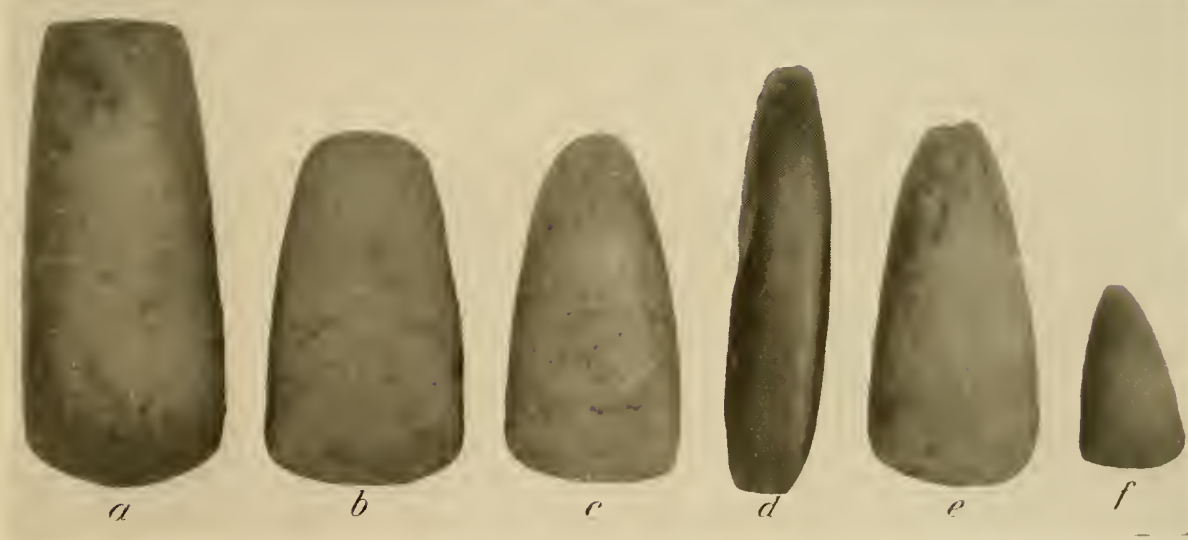

CELTS OF STONE 

Another problem was presented by the finding of a large number of two-pointed stones of the type shown in plate $\mathrm{r}$. These objects are $13 / 4$ to $21 / 4$ inches in length, and one measures $23 / 4$ inches. They are either elliptical or circular in cross-section; most of them are of the latter form. The writer knows of only a single two-pointed stone of this type from elsewhere in the West Indies; this is from Grenada

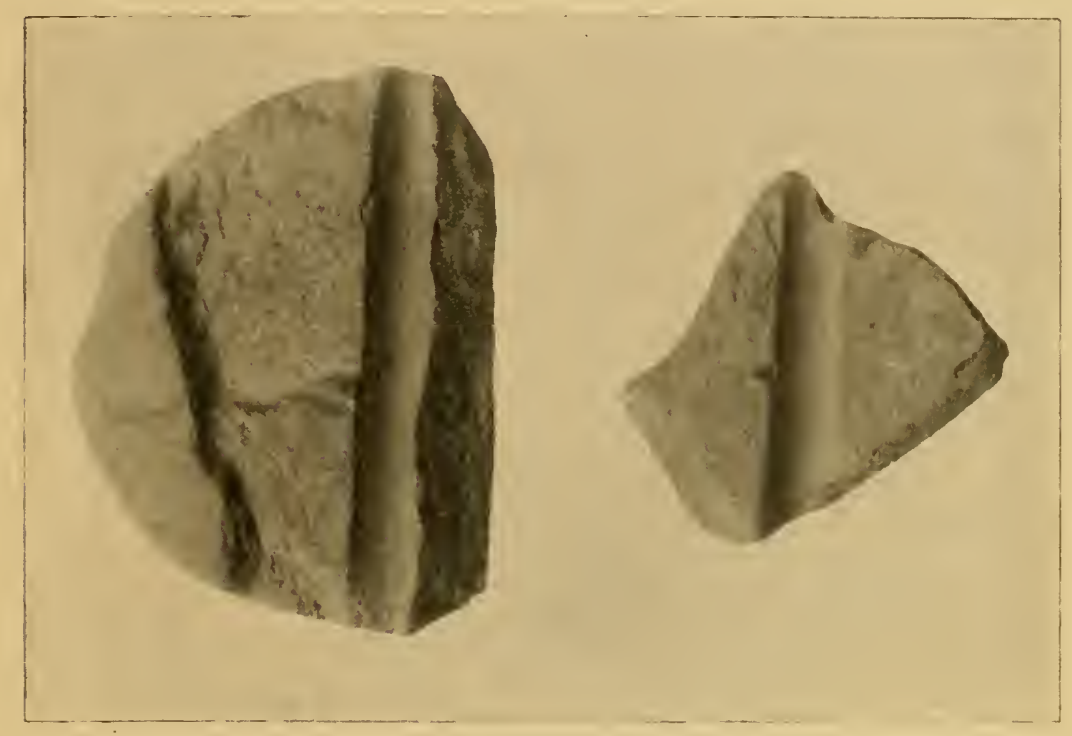

FIG. II.-Arrowshaft rubbers.

and is also in the Museum of the American Indian, which likewise possesses a few similar stones from California. While these twopointed stones are still to be regarded as problematical objects, attention should be called to the fact that if one of them is twirled between the fingers on a smooth surface, it will spin for a considerable time; hence it is not impossible that they may have been used in games or in ceremonies of divination. Nevertheless these stones present an interesting problem in West Indian archeology, both from the comparatively large number (twenty-eight) that were found in Margarita, and from their shape.

The usual types of West Indian celts were also found in Margarita. These vary from the flat-topped example (pl. IV, $a$ ) to the 
smallest petaloid form $(f)$. These celts do not differ from those found on any of the other islands, although all types, including the

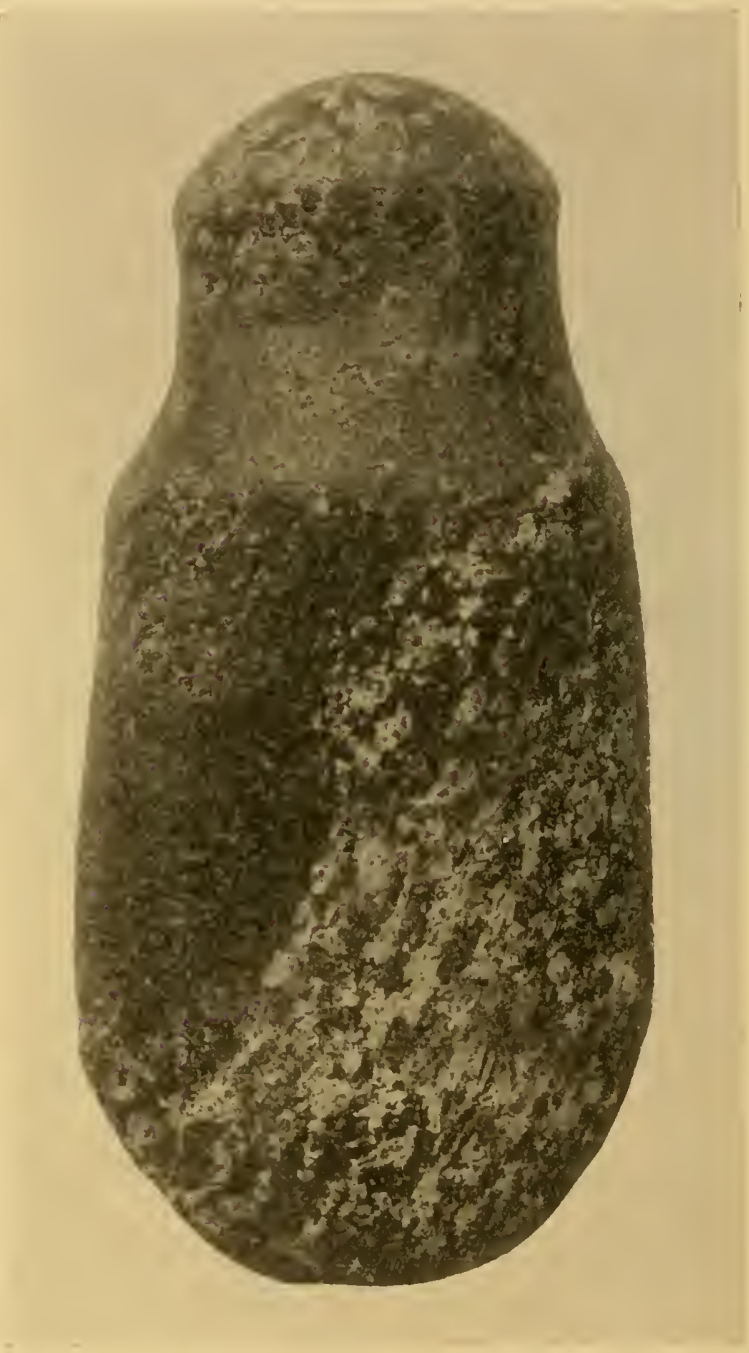

FIG. I 2.-Massive axe. comparatively rare spindleshaped celt $(d)$, were gathered. A few celts from Margarita are made from the lip of the conch. A number of massive axes, of which some are shown in plate $\mathrm{v}, d, e, f$, were found; these differ from the axes found on the islands to the eastward. These implements have a smooth, polished rounded head, and a shallow groove to facilitate hafting. Most of the specimens show signs of use. They range in length from $61 / 2$ to 7 inches.

The Guiana or Brazil type of axe, of which specimens are shown in plate $\mathrm{v}, a, b, c$, was also found in Margarita. In the Museum of the American Indian are a few 

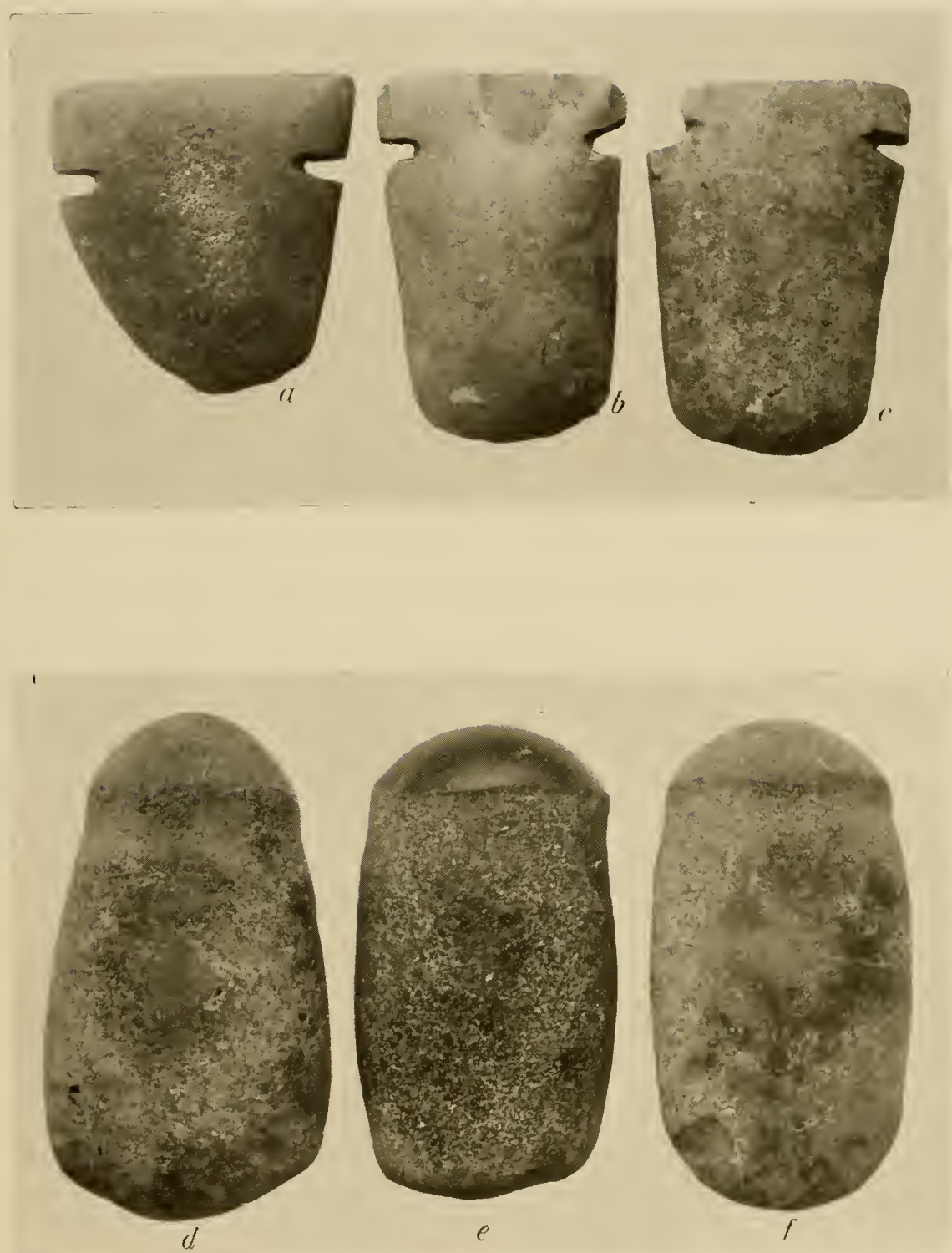

STONE AXES 


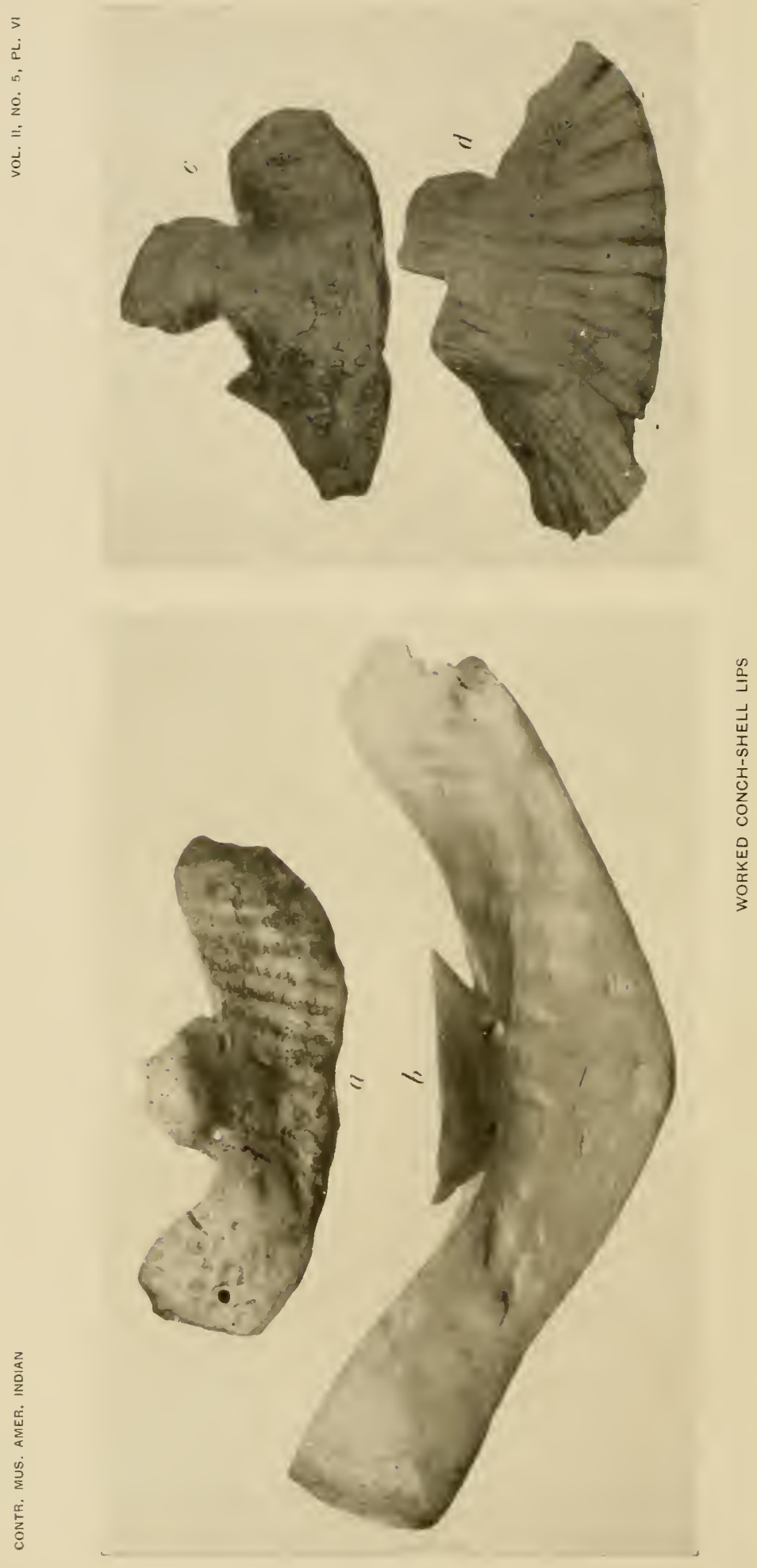
examples of this type from Trinidad, one of which has been figured by Dr Fewkes, ${ }^{1}$ and there is also a specimen from Grenada. The area of the surface where the axe was lashed to the handle is slightly concave in order to facilitate the fastening, a feature common to axes of this form. It has been the custom of the writer to refer to these axes as of the Guiana or Brazil type, as they are found in large numbers in the great region between the mouths of the Orinoco and the Amazon. The axes have also two notches through which the lashing has passed round the handle. Specimen $a$ shows evidence of secondary use, as if employed as a rubbing stone. The length of these axes ranges from $4 \frac{1}{2}$ to 5 inches, with the exception of one from Trinidad which is only 3 inches long.

Still another axe of massive type was found in Margarita; this is shown in figure I2. In outline it approaches $d, e$, and $f$ of plate $r$, but the groove for the hafting is accentuated, and the length of the implement is 8 inches. The example illustrated is the only one of its kind collected in Margarita, but one like it was procured from Rio Caribe on the peninsula of Paria. There is also an axe of this type from Trinidad in the collections of the Museum of the American Indian.

The only axe from Margarita that approaches the types found in the Lesser Antilles is that shown in figure $\mathrm{I} 3$. This miniature implement is only two inches long, but it is identical in form with a number

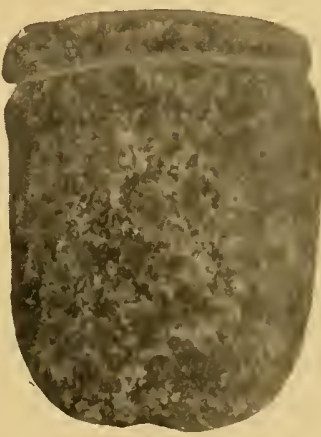

FiG. I3.-Miniature axe. of larger axes from St Vincent, Grenada, and some of the other islands of the Lesser Antilles. A groove surrounds the butt-end, and another groove, not shown in the illustration, extends across the proximal surface.

Only a few objects for personal adornment were found in Margarita. One of these is a small amulet of Amazon stone (fig. I4), which probably represents a highly conventionalized animal form.

${ }^{1}$ J. Walter Fewkes, op. cit., p. 2 I 6. 
The amulet is $\mathrm{I} 3 / 4$ inches in length, is of excellent workmanship, and is drilled for suspension. A shallow pit on each side, above the perforation, may represent the eyes, and under the perforation

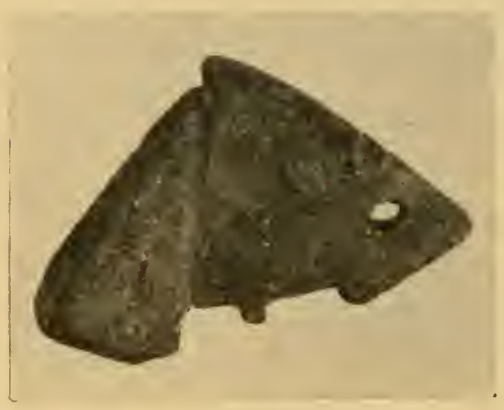

FIG. I4.-Amulet. another pit may have been designed to indicate a nostril. This is the only specimen of Amazon stone found in Margarita.

A number of worked conchshell lips, which may be included among the personal ornaments, were found. Two of these are shown in plate vi, $c, d$. These objects were used probably as pendants. They are far cruder than specimens $a$ and $b$ of plate vI, also in the Museum of the American Indian, from the Andes region of Venezuela, but are similar in type. The reverse side of $b$ is elaborately carved with designs representing human heads; the Margarita specimens are all like specimen $a$, which is devoid of carving. Unlike those from Margarita, the Andean pendants are drilled for suspension; the Margarita specimens, however, narrow slightly at the point where the tongue joins the body of the pendant. A number of pendants made from the lips of conch-shells are figured by Giglioli ${ }^{1}$ that shown in his figure 4 especially resembles those from the Venezuelan Andes above referred to. In all eleven pendants of the kind figured in plate vi, $c, d$, were collected in Margarita.

A single object of hematite (fig. I5) was found in Margarita; it measures $\mathrm{I} 3 / 4$ inches in length, is plummet-shaped, and has a small groove at top and bottom.

A fragmentary bell-shaped pestle (pl. vir, $a$ ), but no entire specimen of this class, was found. This pestle, which is 5 inches in

${ }^{1}$ E. H. Giglioli, " Di certi singolari pettorali in pietra ed in conchiglia precolombiani dalla Venezuela, probabili effigi del dio Vampiro degli antichi indigeni dell' America centrale," Proceedings International Congress of Americanists, I6th Sess., Vienna, I908, vol. 11, pp. 321-330, Vienna, I910. 


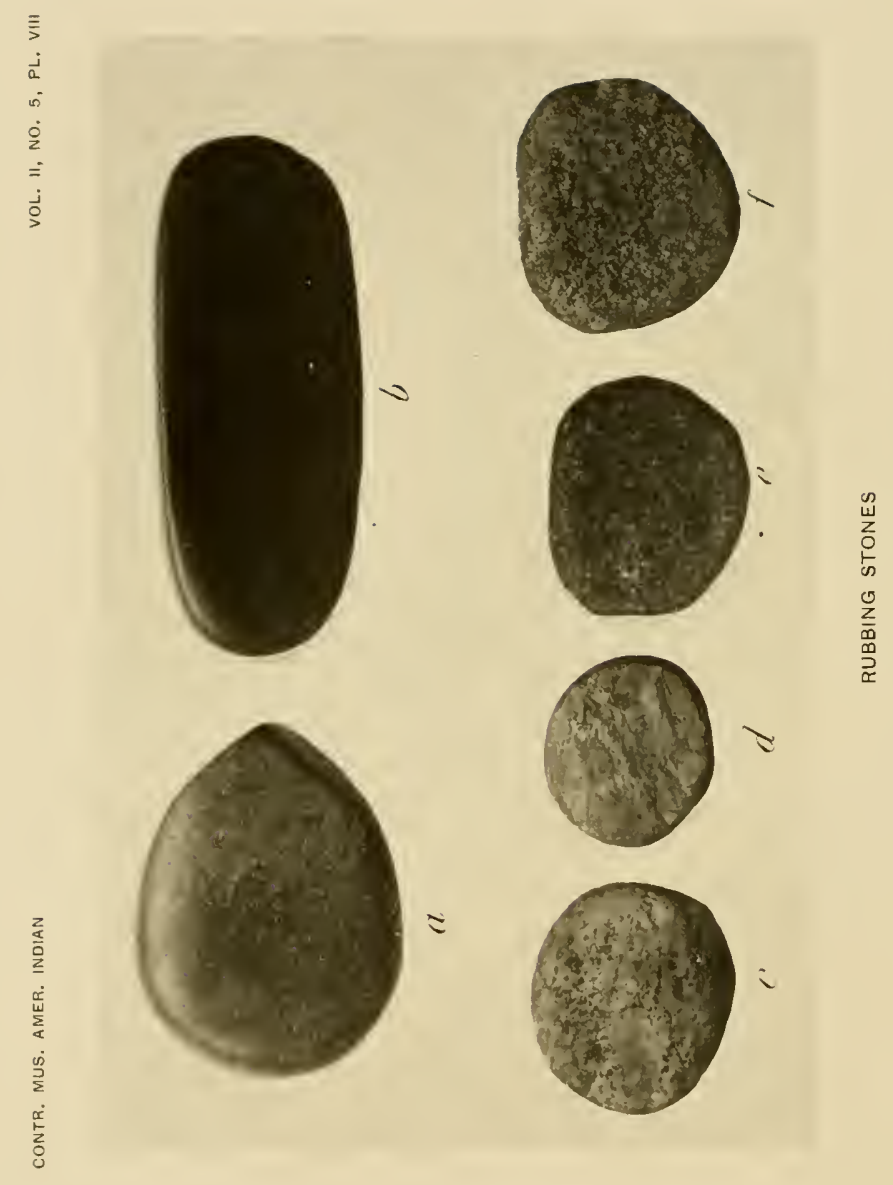


length, recalls similar objects from St Vincent and Grenada, in the Museum of the American Indian.

An unusual hammerstone, 7 inches long, with two grooves, is shown in plate vil, $b$. This form of hammerstone is probably unique. One of the surfaces of the longer axis is slightly flattened, as if to facilitate the lashing of a handle.

In the same plate $(c)$ is figured a stone object of unknown use, 5 inches in length, with two shallow pits, one of which is shown in the illustration. The hammerstone $(d)$ shown in this plate is slightly grooved round the middle and has a shallow pit at each end. The length of this hammer is $23 / 4$ inches, the diameter $2 \frac{1}{2}$ inches.

A number of rubbing-stones are shown in plate

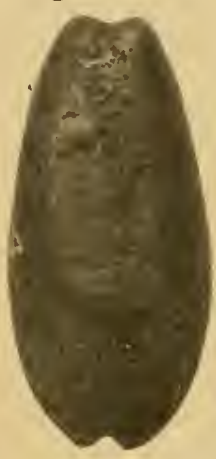

FIG. I5.-Hematite object. virr. Of the smaller stones, $c, d, e$, and $f$ resemble circular discs and range in diameter from one inch to an inch and a quarter. Another rubbing stone $(a)$, shaped like a petaloid celt, is 2 inches long and has a rubbing surface on each side of the point. Still another $(b)$ is $2 \frac{3}{4}$ inches long, and was probably used for smoothing pottery.

It has been seen from the foregoing description of the archeological objects from Margarita that a number resemble specimens from the Carib islands to the eastward. It should not be assumed, however, that the ancient inhabitants of Margarita were necessarily of the same stock as those of the latter islands.

\section{BIBLIOGRAPHY}

Benzovi, Girolamo.............History of the New World. Rear-Admiral Smyth's translation. Hakluyt Society Publications. London, 1857 .

Boor, T. DE.................. Certain Kitchen-middens in Jamaica. American Anthropologist, N. S., vol. xv, no. 3, JulySept. I913; also Contributions from the Heye Museum, vol. I, no. 3, 1913.

2. Pottery from Certain Caves in Eastern Santo Domingo. Ibid., vol. xvir, no. I, Jan.-Mar. I9I5; also Contributions from the Heye Museum, vol. I, no. 9, I9I5. 
Boor, T. DE............... Certain West-Indian Superstitions Pertaining to Celts. Journal of American Folk-Lore, vol. xxviri, no. cvil, Jan.-Mar. 1915; also Contributions from the Museum of the American Indian, vol. II, no. 3, I9I5.

Codazzi, Agustin...............Resumen de la Geografía de Venezuela. Paris, I 84 I.

Dalton, Leonard V........... Venezuela. New York, I912.

Depons, F.................. Voyage to the Eastern Part of Terra Firma or the Spanish Main. New York, I 806.

Fewkes, J. Walter.............Prehistoric Objects from a Shell-heap at Erin Bay, Trinidad. American Anthropologist, N. S. vol. xvi, no. 2, Apr.-June, I9r 4; also Contributions from the Heye Museum, vol. I, no. 7, I9I4.

GIGlioli, E. H. . . . . . . . . . . Di certi singolari pettorali in pietra ed in conchiglia precolombiani dalla Venezuela, probabili effigi del dio Vampiro degli antichi indigeni dell' America centrale. Proceedings International Congress of Americanists, I6th Session, vol. II, Vienna, I910.

НаNDвоок..................... Bureau of American Ethnology, Washington. I $907-10$.

Herrera, Antonio de........... Historia General. Madrid, I 730.

Humboldt, Alexander von.........Personal Narrative. 3d ed., London, 1822.

Level, Andrés A... . . . . . . . Esbozos de Venezuela. Primer Esbozo. La Margarita. Caracas, I88I.

Oviedo, Gonzalo de. . . . . . . . . . . Historia General y Natural de las Indias. Madrid, I $85 \mathrm{I}$.

Scruggs, William L.......... The Colombian and Venezuelan Republics. Boston, I9I0. 


\section{CONTRIBUTIONS}

FROM

\section{THE MUSEUM OF THE AMERICAN INDIAN HEYE FOUNDATION}

\section{CONTENTS OF VOLUME I}

I. Lucayan Artifacts from the Bahamas. THEODOOR DE BoOY.

2. Precolumbian Decoration of the Teeth in Ecuador, with some Account of the Occurrence of the Custom in Other Parts of North and South America. Marshall H. Saville.

3. Certain Kitchen-middens in Jamaica. THEODOOR DE BOOY.

4. Porto Rican Elbow-Stones in the Heye Museum, with Discussion of Similar Objects Elsewhere. J. WALTER FEWkEs.

5. Note on the Archeology of Chiriqui. GEORge Grant MaCCuRdy.

6. Petroglyphs of Saint Vincent. British West Indies. THomas HUCKERBY.

7. Prehistoric Objects from a Shell-heap at Erin Bay, Trinidad. J. WALTER FEWKES.

8. Relations of Aboriginal Culture and Environment in the Lesser Antilles. J. WALter FEWKEs.

9. Pottery from Certain Caves in Eastern Santo Domingo, Wes! Indies. THEODOOR DE BOOY. 
